OPEN ACCESS

Edited by:

Anca Dorhoi,

Friedrich-Loeffler-Institute, Germany

Reviewed by:

Philip Alexander Efron, University of Florida, United States

Thierry Roger,

Centre Hospitalier Universitaire Vaudois (CHUV), Switzerland

${ }^{*}$ Correspondence: Mohamed El Gazzar elgazzar@etsu.edu

Specialty section: This article was submitted to Microbial Immunology, a section of the journal

Frontiers in Immunology

Received: 27 November 2021 Accepted: 06 January 2022

Published: 28 January 2022

Citation:

Bah I, Youssef D, Yao ZQ, McCall CE and El Gazzar M (2022) Inhibiting KDM6A Demethylase Represses Long Non-Coding RNA Hotairm1 Transcription in MDSC During Sepsis.

Front. Immunol. 13:823660. doi: 10.3389/fimmu.2022.823660

\section{Inhibiting KDM6A Demethylase Represses Long Non-Coding RNA Hotairm1 Transcription in MDSC During Sepsis}

\author{
Isatou Bah ${ }^{1}$, Dima Youssef ${ }^{1}$, Zhi Q. Yao ${ }^{1}$, Charles E. McCall ${ }^{2}$ and Mohamed El Gazzar ${ }^{1 *}$ \\ 1 Department of Internal Medicine, East Tennessee State University College of Medicine, Johnson City, TN, United States, \\ ${ }^{2}$ Department of Internal Medicine, Section of Molecular Medicine, Wake Forest University School of Medicine, \\ Winston-Salem, NC, United States
}

Myeloid-derived suppressor cells (MDSCs) prolong sepsis by promoting immunosuppression. We reported that sepsis MDSC development requires long non-coding RNA Hotairm1 interactions with S100A9. Using a mouse model that simulates the immunobiology of sepsis, we find that histone demethylase KDM6A promotes Hotairm1 transcription by demethylating transcription repression H3K27me3 histone mark. We show that chemical targeting of KDM6A by GSK-J4 represses Hotairm1 transcription, which coincides with decreases in transcription activation H3K4me3 histone mark and transcription factor PU.1 binding to the Hotairm1 promoter. We further show that immunosuppressive IL-10 cytokine promotes KDM6A binding at the Hotairm1 promoter. IL-10 knockdown repletes H3K27me3 and reduces Hotairm1 transcription. GSK-J4 treatment also relocalizes nuclear S100A9 protein to the cytosol. To support translation to human sepsis, we demonstrate that inhibiting H3K27me3 demethylation by KDM6A ex vivo in MDSCs from patients with protracted sepsis decreases Hotairm1 transcription. These findings suggest that epigenetic targeting of MDSCs in human sepsis might resolve post-sepsis immunosuppression and improve sepsis survival.

Keywords: sepsis, KDM6A, Hotairm1, MDSC, immune suppression

\section{INTRODUCTION}

Sepsis is a life-threatening organ dysfunction caused by a dysregulated host response to infection and a leading cause of death and critical illness $(1,2)$. Sepsis may enable a profound innate and adaptive immune suppression following its acute hyperinflammatory response (3-5). The immunosuppressive state causes CD4 and CD8 T cell exhaustion $(3,6)$, incites new infections 
and reactivates latent viruses $(7,8)$, increases the incidence of chronic critical illness (9), and raises morbidity and mortality rates $(3,9)$. There are no molecular-targeted sepsis treatments.

Myeloid-derived suppressor cells (MDSCs) are pathologically activated neutrophils and monocytes that emerge from myeloid progenitors during aberrant stimulation of myeloid progenitors/ precursors with cytokines and growth factors, and which enter sites of infection and inflammation (10-12). MDSCs continue to increase in blood, spleen, and bone marrow in mice and humans with sepsis, contributing to the protracted sepsis phenotype (1316), called persistent inflammation, immunosuppression, and catabolism syndrome (PICS) $(9,15)$. We previously reported that MDSCs generation in a clinically relevant mouse sepsis model and in septic humans is supported by nuclear accumulation of inflammatory protein, S100A9 (17). Mice deficient in S100A9 fail to generate MDSCs and protracted sepsis (17). Accordingly, nuclear S100A9 protein promotes immunosuppressive MDSCs (17). We also reported that levels of lncRNA Hotairm1 in MDSCs increase in mice with later/protracted sepsis (18). Hotairm1 transfers cytosolic S100A9 to the nucleus in MDSCs, at least in part, to drive MDSC immunosuppressive effects.

Epigenetic mechanisms maintain homeostasis, as well as increase and decrease in gene transcription [reviewed in (19)]. Infection-induced epigenetic changes in innate immunity cells can prolong immunosuppression during later/chronic sepsis (20-22). Immunosuppression associated with later sepsis leads to secondary infections and mounting mortality (3, 20, 23). Using the polymicrobial mouse model of sepsis, we discovered an epigenetic signature directed by the histone lysine demethylase, KDM6A, in MDSCs from mice with later sepsis (24). In this study, we extended our mechanistic and translational research by identifying KDM6A as a promoter of the epigenetic exchanges that induce Hotairm1 transcription in MDSCs during sepsis.

KDM6A, also known as UTX, belongs to the H3K27me3specific demethylase subfamily, KDM6. KDM6 demethylases contain a JmjC catalytic domain that demethylates tri-methylated Lys 27 on histone $\mathrm{H} 3$ (H3K27me3) to promote gene activation (25-27). Depletion of KDM6A also increases H3K27me3 to silences HOX genes during myeloid cell differentiation $(25,28)$. Targeting KDM6A reduces inflammatory responses in human macrophages (29). KDM6A binding to the Hotairm1 promoter in MDSCs from mice with later sepsis correlates with Hotairm1 transcription activation (24).

Here, we found that KDM6A specific inhibitor GSK-J4 supports an exchange between $\mathrm{H} 3 \mathrm{~K} 27 \mathrm{me} 3$ and $\mathrm{H} 3 \mathrm{~K} 4 \mathrm{me} 3$ at Hotairm1 promoter in mouse and human MDSCs, thereby mediating the effect of other bioactive mediators of sepsis immunosuppression (e.g., IL-10).

\section{MATERIALS AND METHODS}

\section{Mice}

Male C57BL/6 mice ( 8 to 10 weeks old) were purchased from the Jackson Laboratory (Bar Harbor, ME) and housed in a pathogen- free facility. All experiments were conducted according to National Institutes of Health guidelines and were approved by the East Tennessee State University Animal Care and Use Committee.

Several clinical and experimental studies have shown that cell-mediated immune responses are depressed in males while enhanced in females during sepsis $(30,31)$ and that the female mouse is more immunologically competent than the male mouse in surviving CLP insult (32). And because MDSCs suppress both innate and adaptive immune responses, we used male mice to assess the maximal effect of this immunosuppressive cell population on sepsis outcome.

\section{Induction of Sepsis}

Polymicrobial sepsis was induced by cecal ligation and puncture (CLP) as described previously (33). Briefly, a midline abdominal incision was made, and the cecum was ligated distal to the ileocecal valve and punctured twice with a 23-gauge needle. A small amount of feces was extruded into the abdominal cavity. Mice received (i.p.) $1 \mathrm{ml}$ lactated Ringers plus $5 \%$ dextrose for fluid resuscitation. To establish intraabdominal infection and approximate the clinical condition of human sepsis (34) and delay in MDSC development, mice were subcutaneously administered antibiotic (imipenem; $25 \mathrm{mg} / \mathrm{kg}$ body weight) in $0.9 \%$ saline at 8 and $16 \mathrm{~h}$ after CLP. These manipulations result in acute sepsis and post-sepsis phases, with high mortality ( $60-70 \%)$ during the post-sepsis phase (13). Survival was followed for 28 days. Mice moribund during early sepsis (defined as the first 5 days after CLP) or later sepsis (day 7-28) (33) were euthanized and analyzed. Mice were considered moribund if they experienced hypothermia $\left(<34^{\circ}\right.$ C) or loss of righting reflex. A corresponding number of mice from the control/sham group were also analyzed at the same time point.

\section{Patients}

Patients 18 years or older admitted to Johnson City Medical Center and Franklin Woods Community Hospital in Johnson City, Tennessee with sepsis or septic shock participated in the study. Sepsis patients were identified based on the presence of documented or suspected infection along with an acute increase of $\geq 2$ points in SOFA (sequential organ failure assessment) score (1). The baseline SOFA score is assumed to be zero in patients without preexisting organ dysfunctions, which are determined by $\mathrm{PaO} 2$, platelets count, Glasgow Coma Scale score, creatinine, and bilirubin levels. Septic shock patients presented with persistent hypotension requiring vasopressors to maintain MAP $\geq 65 \mathrm{~mm} \mathrm{Hg}$ and had serum lactate $>2 \mathrm{mmol} /$ L despite adequate fluid resuscitation (1). Patients presented with infections related to gram-negative or gram-positive bacteria, and the primary sites of infection included the urinary tract, circulation, and respiratory tract. Patients had at least 1 comorbid condition, such as nephropathy, psoriasis, splenectomy, colon cancer, or pulmonary disease. Patients with leukopenia due to chemotherapy or with glucocorticoid therapy or HIV infection were excluded. Patients were in two 
categories: early sepsis and later sepsis (i.e., protracted sepsis), based on time of diagnosis. The early sepsis group within 1-5 days of sepsis diagnosis and later sepsis more than 6 days. Later sepsis blood procurement occurred at days 6-68 after sepsis diagnosis. Blood samples obtained from healthy control subjects were supplied by BioIVT (Gray, TN). A total of 18 sepsis patients and 10 healthy subjects are included in this study. The study was approved by the Institutional Review Board (IRB) of the East Tennessee State University (IRB\#: 0714.6s). Signed informed consent was obtained from all participants.

\section{Myeloid-Derived Suppressor Cells (MDSCs)}

$\mathrm{Gr}^{+} \mathrm{CD} 11 \mathrm{~b}^{+} \mathrm{MDSC}$ were isolated from mouse bone marrow by negative selection using EasySep mouse MDSC isolation kit (Cat\# 19867) according to the manufacturer's protocol (Stemcell Technologies, Cambridge, MA). Briefly, the bone marrow was flushed out of the femurs with RPMI-1640 medium under aseptic conditions. A single-cell suspension was made by filtering through a $70 \mu \mathrm{m}$ mesh nylon strainer, followed by incubation with erythrocyte lysis buffer and washing. The cell suspension was incubated with a biotin-coupled antibody cocktail (binds to all non-Gr1 $1^{+} / \mathrm{CD} 11 \mathrm{~b}^{+}$cells) at room temperature for $10 \mathrm{~min}$, followed by adding streptavidincoated magnetic particles and incubating at room temperature for $5 \mathrm{~min}$. Sample tubes were placed into a magnet for $3 \mathrm{~min}$, and the enriched (flow-through) cell suspension containing $\mathrm{Gr}^{+} \mathrm{CD} 11 \mathrm{~b}^{+}$cells was transferred to a fresh tube. The cells were more than $90 \% \mathrm{Grl}^{+}$and $\mathrm{CD} 1 \mathrm{~b}^{+}$positive as determined by flow cytometry. For cell culture, the $\mathrm{Gr} 1^{+} \mathrm{CD} 11 \mathrm{~b}^{+}$cells were incubated with RPMI-1640 medium (Invitrogen, Carlsbad, CA) supplemented with $100 \mathrm{U} / \mathrm{ml}$ penicillin, $100 \mu \mathrm{g} / \mathrm{ml}$ streptomycin, 2 mM L-glutamine (HyClone Laboratories, Logan, UT), and 10\% fetal bovine serum (Atlanta Biologicals, Lawrenceville, GA) at $37^{\circ} \mathrm{C}$ and $5 \% \mathrm{CO}_{2}$.

For human MDSCs, peripheral blood mononuclear cells were isolated from whole blood by density gradient centrifugation using Ficoll-Paque Plus according to the manufacturer's protocol (GE Healthcare Life Sciences, Marlborough, MA), and then depleted of $\mathrm{HLA}-\mathrm{DR}^{+}$cells via positive selection using a biotin-coupled anti-HLA-DR antibody (Cat\# 13-9956-82, eBioscience, San Diego, CA) and anti-biotin microbeads (Miltenyi Biotec, Auburn, CA). Next, the remaining cells were positively selected using biotin-coupled anti-CD33 (Cat\# MA119522, Invitrogen) and anti-LOX-1 antibodies (Cat\# 130-122119) (Milteny Biotec).

For inhibition of KDM6A demethylase activity, GSK-J4 $\mathrm{HCl}$ (Cat\# S7070, Selleckchem, Houston, TX) was reconstituted in DMSO at variable concentrations. A $0.1 \%$ DMSO was used as a control.

\section{Knockdown of IL-10}

Inhibition of IL-10 in $\mathrm{Gr}^{+} \mathrm{CD}^{+} 1 \mathrm{~b}^{+}$cells was performed using pools of gene-specific or scrambled (control) siRNAs (Santa
Cruz Biotechnology, Dallas, TX). The siRNA mixture was suspended in HiPerFect reagent (Qiagen, Germantown, MD) at a $0.5 \mu \mathrm{M}$ final concentration. The cells were transfected and incubated with RPMI-1640 medium for $36 \mathrm{~h}$.

\section{Chromatin Immunoprecipitation (ChIP)}

ChIP was performed using ChIP-IT Express Enzymatic Shearing kit according to the manufacturer's protocol (Active Motif, Carlsbad, CA). Briefly, mouse $\mathrm{Gr} 1^{+} \mathrm{CD} 11 \mathrm{~b}^{+}$ cells and human $\mathrm{CD} 84^{+} \mathrm{LOX} 1^{+} \mathrm{HLA}-\mathrm{DR}^{-}$cells were isolated and fixed in $1 \%$ formaldehyde in a minimal culture medium at room temperature for $10 \mathrm{~min}$, to cross-link DNA-protein complexes. After washing, cells were resuspended in lysis buffer containing protease inhibitor cocktail and incubated on ice for $1 \mathrm{~h}$. The cell lysate was cleared by centrifugation at $5,000 \mathrm{rpm}$ and $4^{\circ} \mathrm{C}$ for $10 \mathrm{~min}$. The pelleted nuclei were then resuspended in digestion buffer containing an enzymatic shearing cocktail and incubated at $37^{\circ} \mathrm{C}$ for $10 \mathrm{~min}$. The sheared chromatin (supernatant) was recovered by centrifugation at $15,000 \mathrm{rpm}$ for $10 \mathrm{~min}$ at $4^{\circ} \mathrm{C}$. Ten microliters of the chromatin solution was reserved as an "input DNA" sample. Next, $5 \mu \mathrm{g}$ of antibody against KDM6A (Cat\# 33510S, Cell Signaling Technology), PU.1 (Cat\# MA5-15064, Invitrogen), H3K4me3 (Cat\# MBS9401981), H3K27me3 (Cat\# MBS3010330) (MyBioSource, San Diego, CA), Ezh2/ENX-1 (Cat\# 5246S, Santa Cruz Biotechnology), or isotype control antibody and 25 $\mu \mathrm{l}$ of protein G-coated magnetic beads were added to $150 \mu \mathrm{l}$ of the sheared chromatin, and the chromatin was then immunoprecipitated at $4^{\circ} \mathrm{C}$ overnight with rotation. The chromatin/antibody complexes captured on the beads were washed three times in ChIP buffer and eluted by incubation for 15 min in $50 \mu$ l elution buffer. The DNA-protein cross-links were reversed by adding $50 \mu \mathrm{l}$ of reverse cross-linking buffer to the eluted chromatin and the samples were incubated, along with the "input" $\mathrm{DNA}$, at $95^{\circ} \mathrm{C}$ for $15 \mathrm{~min}$. After treatment with $5 \mu \mathrm{l}$ of proteinase $\mathrm{K}$ at $37^{\circ} \mathrm{C}$ for $1 \mathrm{~h}$ (to degrade proteins), the ChIPed DNA was recovered and stored at $-20^{\circ} \mathrm{C}$ until analyzed by PCR as described below.

\section{Quantitative Real-Time PCR}

For ChIP analysis, the ChIPed DNA was amplified by real-time qPCR using QuantiTect SYBR Green PCR Master Mix (Qiagen) and primers designed to amplify a 220 bp fragment that contains a PU.1 binding site at -199 to -194 of the mouse Hotairm 1 promoter. These primers were: PU.1 forward 5'tcccagagtcgccactgccaa-3'; PU.1 reverse 5'-tagagtcacgtgtcctcccc3' (Integrated DNA Technologies, Coralville, IA). For human Hotairm1, we used primers designed to amplify a $220 \mathrm{bp}$ fragment that contains a PU.1 binding site at -195 to -200 (lower strand) of the human Hotairm1 promoter. These primers were: PU.1 forward 5'-gtatggggtattccaggaagg-3'; PU.1 reverse 5'-gaggctcagccattggctga-3'. The PCR reactions were performed in duplicate in $50 \mu \mathrm{l}$ volumes. The cycling conditions were as follows: 1 cycle at $95^{\circ} \mathrm{C}$ for $15 \mathrm{~min}, 35$ 
cycles at $94^{\circ} \mathrm{C}, 58^{\circ} \mathrm{C}$, and $72^{\circ} \mathrm{C}$ for $30 \mathrm{~s}$ each, and a final cycle at $72^{\circ} \mathrm{C}$ for $10 \mathrm{~min}$.

For the analysis of Hotairm1 expression, total RNA was isolated using TRIzol reagent (Invitrogen) and subjected to reverse transcription using QuantiTect Reverse Transcription kit (Qiagen). The cDNA was amplified by real-time qPCR using QuantiTect SYBR Green PCR Master Mix kit and pre-designed qPCR Primer Assays specific to mouse Hotairm1 (assay ID\# LPM17359A) and GAPDH (assay ID\# QT01658692), and human Hotairm1 (assay ID\# LPH10483A) and GAPDH (assay ID\# QT00079247) (all from Qiagen). The expression level was calculated using the $2^{-\Delta \Delta \mathrm{Ct}}$ cycle threshold method. The values were normalized to input DNA or GAPDH RNA level, and the results are presented as a fold change relative to the control samples.

\section{Western Blot}

Whole-cell lysates were prepared using 1x RIPA lysis buffer containing $50 \mathrm{mM}$ Tris- $\mathrm{HCl}$ [pH 7.4], $150 \mathrm{mM} \mathrm{NaCl}, 1 \% \mathrm{NP}-$ 40, $0.25 \%$ sodium deoxycholic acid, $1 \mathrm{mM}$ EDTA (Millipore, Temecula, CA), and 1x protease inhibitor cocktail. Nuclear and cytoplasmic extracts were prepared using the NE-PER nuclear and cytoplasmic extraction kit according to the manufacturer's protocol (Pierce, Rockford, IL). Protein extracts were resolved onto SDS-10\% polyacrylamide gel (Bio-Rad, Hercules, CA) and transferred to nitrocellulose membranes (Thermo Fisher Scientific, Waltham, MA). The membranes were blocked with $5 \%$ milk in Tris-buffered saline/Tween-20 for $1 \mathrm{~h}$ at room temperature and then probed overnight at $4^{\circ} \mathrm{C}$ with an antibody specific to PU.1 (Cat\# MA5-15064, Invitrogen, Carlsbad, CA), Ezh2 (Cat\# 166609), IL-10 (Cat\# sc-32815), S100A9 (Cat\# sc58706) (Santa Cruz Biotechnology), KDM6A (Cat\# 33510S, Cell Signaling Technology, Danvers, MA) antibody. After washing, blots were incubated with the appropriate HRP-conjugated secondary antibody for $2 \mathrm{~h}$ at room temperature. Proteins were detected with the enhanced chemiluminescence detection system (Thermo Fisher Scientific), the bands were visualized using the ChemiDoc XRS System (Bio-Rad), and the images were captured with the Image Lab Software V3.0. The membranes were stripped and reprobed for $\beta$-actin (Invitrogen).

\section{Statistical Analysis}

Data were analyzed with Microsoft Excel, V3.0. Values are expressed as mean $\pm \mathrm{SD}$. Differences between two groups were determined by a two-tailed student's $t$-test. $P$-values of $<0.05$ were considered statistically significant.

\section{RESULTS}

\section{Inhibiting KDM6A Demethylase Activity by GSK-J4 Increases H3K27me3 Levels on the Hotairm1 Promoter}

Our previous studies showed that Hotairm1 modifies the S100A9 protein's function to generate MDSCs during later sepsis $(17,18)$. Hotairm 1 expression in MDSCs is induced by the binding of transcription factor PU.1 to its proximal promoter. This process is facilitated by an exchange of the transcriptional repressive histone mark $\mathrm{H} 3 \mathrm{~K} 27 \mathrm{me} 3$ for the permissive mark $\mathrm{H} 3 \mathrm{~K} 4 \mathrm{me} 3$ as sepsis progresses to the later, protracted state (24). KDM6A is a selective demethylase of $\mathrm{H} 3 \mathrm{~K} 27 \mathrm{me}$, and targeting KDM6A activity in vivo in mice (35) and in human macrophages (29) increases the H3K27me3 level on promoters of target genes. Here, we used KDM6A potent and specific inhibitor GSK-J4 to modulate Hotairm1 RNA transcription in sepsis MDSCs.

ChIP analysis of Hotairm1 promoter showed that KDM6A binding was significantly higher in MDSCs from mice with later sepsis compared with early sepsis. The increase in KDM6A binding was accompanied by a decrease in H3K27me3 and a subsequent increase in PU.1 binding and Hotairm1 transcription [Figures 1A-C and (24)]. We tested whether the inhibition of KDM6A demethylase activity can increase H3K27me3 deposition on the Hotairm 1 promoter. MDSCs from mice with later sepsis, which exhibit the most decrease in $\mathrm{H} 3 \mathrm{~K} 27 \mathrm{me} 3$ and increase in KDM6A binding, were incubated with DMSO or increasing concentrations of GSK-J4 for $12 \mathrm{~h}$. As shown in Figure 1D, H3K27me3 deposit on Hotairm 1 promoter significantly increased in the presence of $4 \mu \mathrm{M}$ concentration of GSK-J4, and its level slightly decreased and plateaued at concentrations higher than $4 \mu \mathrm{M}$. There were no significant differences in cell death as determined by trypan blue staining within the $2-10 \mu \mathrm{M}$ concentration range (data not shown).

We next used $4 \mu \mathrm{M}$ concentration to determine the optimal incubation time for the GSK-J4 effect on KDM6A inhibition. MDSCs treated with GSK-J4 for $12 \mathrm{~h}$ exhibited the highest increase in $\mathrm{H} 3 \mathrm{~K} 27 \mathrm{me} 3$ compared to 24 or $48 \mathrm{~h}$ (Figure 1E). In addition, treatment with $4 \mu \mathrm{M}$ for $12-48 \mathrm{~h}$ did not affect the cellular levels of KDM6A (Figure 1F) or Ezh2 protein, which trimethylates H3K27 in MDSCs (24). Therefore, we used $4 \mu \mathrm{M}$ concentration and $12 \mathrm{~h}$ incubation time in all subsequent experiments.

\section{Inhibiting KDM6A Activity Decreases H3K4me3 Levels on Hotairm1 Promoter in MDSCs}

KDM6A protein binds to Hotairm1 proximal promoter following sepsis initiation, and its binding peaks in later sepsis MDSCs (24). KDM6A decreases H3K27me3 and simultaneously increases the transcriptional permissive mark H3K4me3 (24). Chromatin collected from MDSCs isolated from sham and septic mice was used to analyze levels of KDM6A, H3K27me3, and H3K4me3 following treatment with $4 \mu \mathrm{M}$ GSK-J4 for $12 \mathrm{~h}$, using ChIP assay. GSK-J4 treatment did not affect KDM6A binding at the Hotairm1 promoter (Figure 2A). Notably, inhibition of KDM6A demethylase activity markedly increased H3K27me3 and nearly diminished H3K4me3 deposit on the promoter (Figures 2B, C). These results support that GSK-J4 effectively inhibits KDM6A demethylase activity and increases the amount of $\mathrm{H} 3 \mathrm{~K} 27 \mathrm{me} 3$ on the Hotairm 1 promoter in MDSCs. 


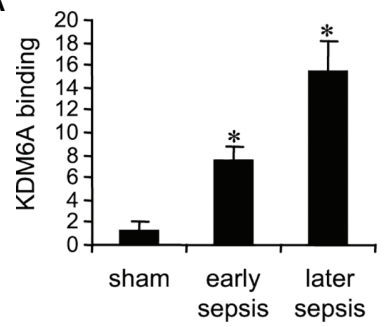

B

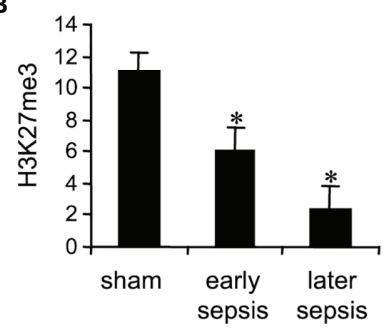

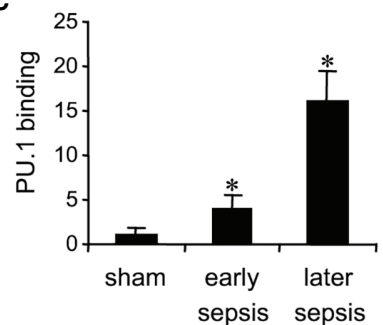

later sepsis MDSCs

D

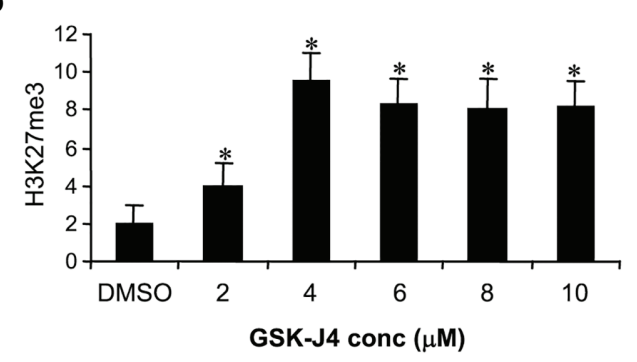

$\mathbf{E}$

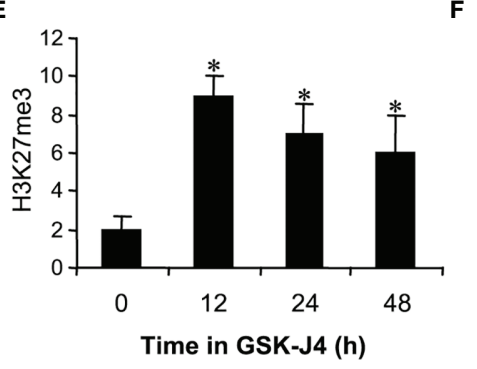

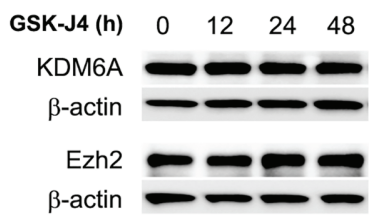

FIGURE 1 | Inhibition of KDM6A in MDSCs increases H3K27me3 on the Hotairm1 promoter. (A) Gr1 ${ }^{+}$CD11 ${ }^{+}$cells were purified from bone marrow cells by negative selection using magnetic beads and anti-Gr1 and anti-CD11b antibodies. (A-C) Chromatin immunoprecipitation (ChIP) assay to detect KDM6A, H3K27me3, and PU.1 at Hotairm1 promoter. Chromatin was immunoprecipitated with anti-KDM6A, anti-H3K27me3, anti-PU.1, or anti-IgG control antibody. The ChIPed DNA was analyzed by real-time qPCR. Samples values were normalized to the "input" DNA (DNA isolated before the immunoprecipitation) and are presented relative to the lgG-immunoprecipitated samples (set at 1-fold). (D) Dose-dependent inhibition of KDM6A. The Gr1 ${ }^{+} \mathrm{CD} 11 \mathrm{~b}^{+}$cells were incubated with varying concentrations of KDM6A inhibitor GSK-J4 in DMSO or $0.1 \%$ DMSO alone for $12 \mathrm{~h}$. (E) Time-dependent inhibition of KDM6A. The cells were incubated with $4 \mu \mathrm{M}$ of GSK-J4 for the indicated times. Chromatin was immunoprecipitated with anti-H3K27me3 antibody. Data represent mean \pm SD for 5-6 mice per group, pooled from independent experiments. ${ }^{*} p<0.05$, early or later sepsis vs. sham (A-C); ${ }^{*} p<0.05$, vs. DMSO (D); ${ }^{*} p<0.05$, vs. 0 h (E). (F) Western blotting of Ezh2 and KDM6A in $\mathrm{Gr} 1^{+} \mathrm{CD} 11 \mathrm{~b}^{+}$cells following GSK-J4 inhibition. The results are representative of two Western blots.

\section{Inhibiting KDM6A Activity Decreases PU.1 Binding and Transcription in MDSCs}

Transcription of Hotairm1 RNA in MDSCs during sepsis is induced by PU.1 binding at its proximal promoter, which is dependent on the demethylation of H3K27me3 by KDM6A and the deposit of H3K4me3 (24). We next assessed the effect of KDM6A inhibition on PU.1 binding and Hotairm1 transcript levels. Hotairm1 levels were normalized to GAPDH. Note GAPDH expression is not stable during sepsis. GSK-J4 treatment for $12 \mathrm{~h}$ significantly reduced Hotairm 1 transcripts, with a pattern that mirrored a decrease in PU.1 binding (Figure 3). These findings supported our hypothesis that removal of H3K27me3 from Hotairm1 promoter via KDM6Amediated demethylation plays a major role in the induction of Hotairm1 in MDSCs during sepsis.

\section{IL-10 Induces KDM6A Binding at Hotairm1 Promoter in MDSCs}

The immunosuppressive IL-10 cytokine, whose levels increase significantly during later sepsis, promotes the Hotairm1mediated shuttling of S100A9 protein to the nucleus in
MDSCs (36). We have recently shown that the programming of myeloid precursors into immunosuppressive MDSCs in later sepsis is dependent on IL-10 (18). We hypothesized that IL-10 induces this process by promoting KDM6A-mediated induction of Hotairm1. To test this hypothesis, we knocked down IL-10 in MDSCs and assessed KDM6A binding and H3K27me3 and H3K4me3 levels at Hotairm1 promoter using ChIP assay. Western blotting showed the knockdown was efficient in reducing IL-10 protein (Figure 4A). Notably, the binding of KDM6A at the Hotairm1 promoter was significantly reduced (Figure 4B). The decrease in KDM6A binding significantly increased $\mathrm{H} 3 \mathrm{~K} 27 \mathrm{me} 3$ and decreased $\mathrm{H} 3 \mathrm{~K} 4 \mathrm{me} 3$ levels on the Hotairm1 promoter (Figures 4C, D). These changes were not due to a decrease in KDM6A expression, because KDM6A protein level was not affected by IL-10 knockdown (Figure 4E).

Next, we determined PU.1 binding and Hotairm1 transcript levels after IL-10 knockdown. As shown in Figures 5A, B, depletion of IL-10 resulted in significant decreases in PU.1 binding and Hotairm1 transcripts. These findings suggest that IL-10 induces the epigenetic changes that promote Hotairm1 transcription in MDSCs during sepsis. 
A

- DMSO

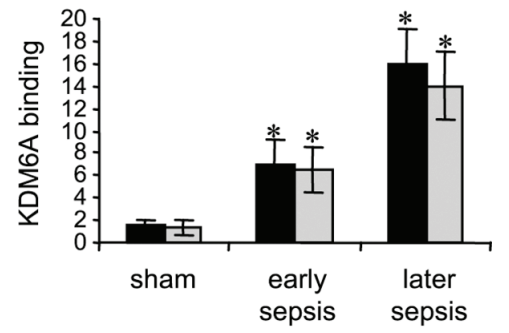

B

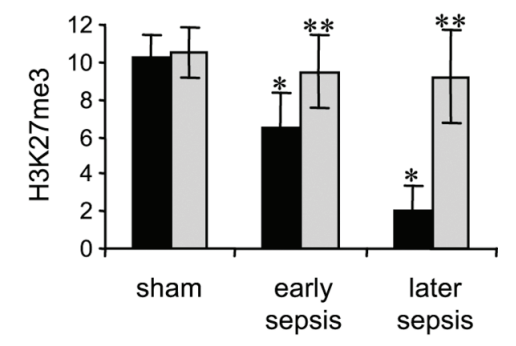

C

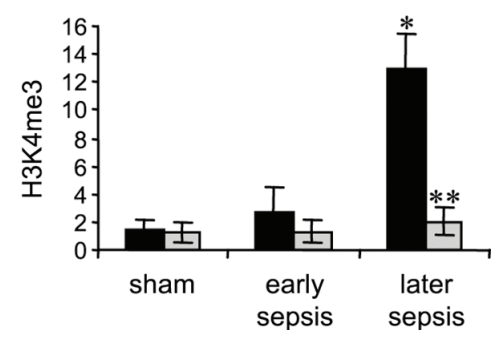

FIGURE 2 | Inhibition of KDM6A in MDSCs decreases H3K4me3 on the Hotairm 1 promoter. $\mathrm{Gr}^{+}{ }^{+} \mathrm{CD} 11 \mathrm{~b}^{+}$cells were purified from bone marrow cells by negative selection using magnetic beads and anti-Gr1 and anti-CD11b antibodies. The cells were incubated with $4 \mu \mathrm{M}$ of GSK-J4 or $0.1 \%$ DMSO for $12 \mathrm{~h}$. Chromatin was isolated as described in Figure $\mathbf{1}$ and then immunoprecipitated with anti-KDM6A (A), anti-H3K27me3 (B), anti-H3K4me3 (C), or IgG control antibody. The ChIPed DNA was analyzed by qPCR as described in Figure 1. Data represent mean \pm SD for 4-6 mice per group, pooled from independent experiments. ${ }^{*} p<0.05$, early or later sepsis vs. sham; ${ }^{* *} p<0.5$, GSK-J4 vs. DMSO.

\section{Inhibiting KDM6A Activity Relocalizes S100A9 to the Cytosol in MDSCs}

Hotairm1 shuttles S100A9 protein to the nucleus in myeloid precursors to program them into MDSCs during later sepsis (18). Because the results described above showed that inhibition of KDM6A suppressed Hotairm1 transcription, we assessed the effect of KDM6A inhibition on S100A9 protein localization. MDSCs were treated with DMSO or GSK-J4 for $12 \mathrm{~h}$, and nuclear and cytosolic extracts were analyzed by Western blotting. GSK-J4 treatment resulted in S100A9 relocalization to the cytosol in later MDSCs, similar to early sepsis MDSCs, which are not immunosuppressive (Figure 5C). These results suggest
A

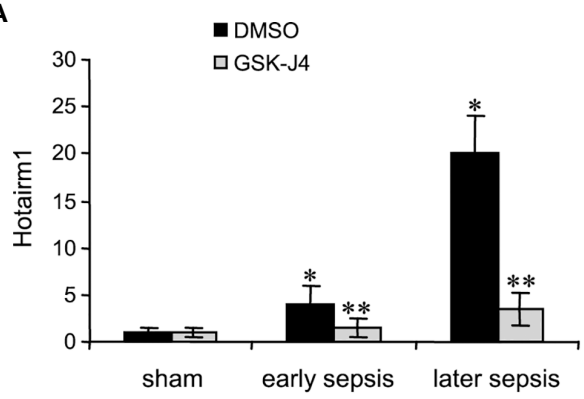

B

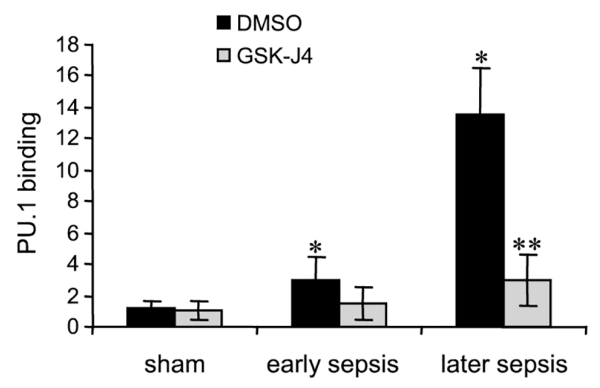

FIGURE 3 | Inhibition of KDM6A in MDSCs reduces Hotairm1 transcription. Gr1 $1^{+} \mathrm{CD} 11 \mathrm{~b}^{+}$cells were purified from bone marrow cells by negative selection using magnetic beads and anti-Gr1 and anti-CD11b antibodies. The cells were incubated with $4 \mu \mathrm{M}$ of GSK-J4 or $0.1 \%$ DMSO for 12 h. (A) Total RNA was isolated and Hotairm1 levels were determined by real-time RT-qPCR using qPCR Primer Assay specific to Hotairm1. Sample values were normalized to GAPDH RNA as an internal control and are presented relative to sham (1-fold). (B) KDM6A inhibition reduces PU.1 binding at the Hotairm1 promoter. Chromatin was isolated as described in (A) and immunoprecipitated with anti-PU.1 or anti-lgG control antibody. The ChIPed DNA was analyzed by qPCR as described in (A). Data represent mean \pm SD for 5-6 mice per group, pooled from independent experiments. Data in (A) are presented relative to sham and data in (B) are presented relative to the IgG-immunoprecipitated samples (1-fold). ${ }^{\star} p<0.05$, early or later sepsis vs. sham; ${ }^{\star *} p<0.05$, GSK-J4 vs. DMSO.

that induction of Hotairm 1 due to $\mathrm{H} 3 \mathrm{~K} 27 \mathrm{me} 3$ demethylation by KDM6A is pivotal in targeting S100A9 protein to the nucleus in later MDSCs.

\section{GSK-J4 Treatment in MDSCs From Sepsis Patients Inhibits KDM6A Demethylase Activity and Hotairm1 Transcription}

MDSCs were isolated from the peripheral blood from patients with early sepsis and those that developed a later, protracted sepsis state. The cells were treated with DMSO or GSK-J4 for $12 \mathrm{~h}$. ChIP assays revealed that GSK-J4 treatment did not affect KDM6A binding at human Hotairm1 promoter (Figure 6A). Inhibition of KDM6A activity significantly increased $\mathrm{H} 3 \mathrm{~K} 27 \mathrm{me} 3$ levels on the promoter, which resulted in a significant decrease in $\mathrm{H} 3 \mathrm{~K} 4 \mathrm{me} 3$ levels (Figures 6B, C). Importantly, this increase in $\mathrm{H} 3 \mathrm{~K} 27 \mathrm{me} 3$ prevented PU.1 binding and subsequent activation of Hotairm 1 transcription, 


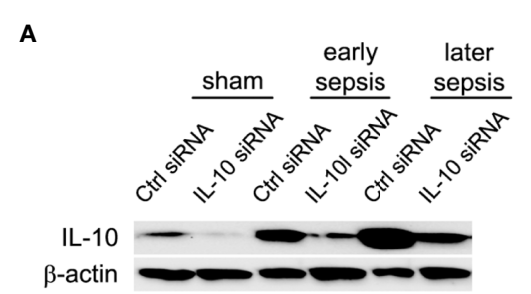

C

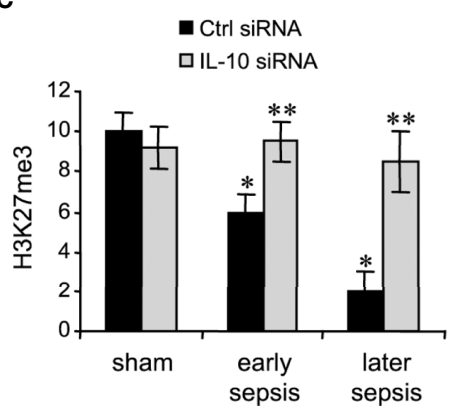

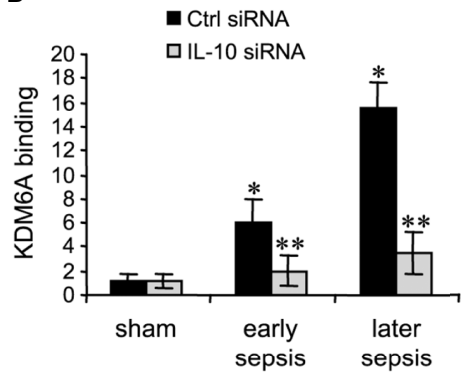

E

D

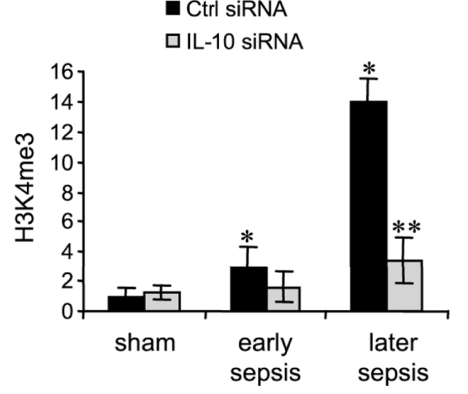

later sepsis MDSCs

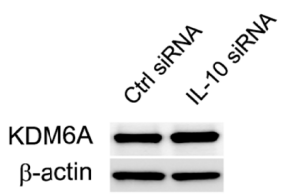

FIGURE 4 | Knockdown of IL-10 in MDSCs inhibits KDM6A binding at the Hotairm1 promoter. Gr1 ${ }^{+} \mathrm{CD} 11 \mathrm{~b}^{+}$cells were purified from bone marrow cells by negative selection using magnetic beads and anti-Gr1 and anti-CD11b antibodies. The cells were transfected with IL-10-specific or scrambled/control siRNA for $36 \mathrm{~h}$. (A) Western blotting of IL-10 following the knockdown. The results are representative of two Western blots. (B-D) Chromatin was isolated as described in Figure 1 and then immunoprecipitated with anti-KDM6A, anti-H3K27me3, anti-H3K4me3, or anti-IgG control antibody. The ChIPed DNA was analyzed by qPCR using primers that amplify the promoter sequences surrounding PU.1 binding site. Samples values were normalized to the "input" DNA and are presented relative to the IgG-immunoprecipitated samples (1-fold). Data represent mean \pm SD for $4-5$ mice per group, pooled from independent experiments. ${ }^{*} p<0.05$, early or later sepsis vs. sham; ${ }^{* *} p<0.05$, IL-10 siRNA vs. Ctrl siRNA. (E) Western blotting of KDM6A following IL-10 after the knockdown. The results are representative of two Western blots. Ctrl, control.

as demonstrated by the significant decrease in Hotairm 1 transcripts (Figures 6D, E). In addition, Western blotting showed that GSK-J4 did not impact the cellular level of KDM6A protein (Figure 6F). These results support that GSK-J4 effectively inhibits KDM6A demethylase activity and targets epigenetic-mediated Hotairm 1 transcription in human MDSCs during sepsis.

\section{DISCUSSION}

The major finding of this study is that targeting KDM6A demethylase using GSK-J4 inhibits Hotairm1 transcription in mouse and human MDSCs. GSK-14 acts by inhibiting KDM6A demethylase activity (depicted in Figure 7) that catalyzes the removal of the methyl groups from tri-methylated histone lysine 27, H3K27me3 (29, 35). Mechanistically, KDM6A demethylates the transcription repressive $\mathrm{H} 3 \mathrm{~K} 27 \mathrm{me} 3$ mark that is deposited on the Hotairm 1 promoter as sepsis progresses to the later, protracted state. Furthermore, countering $\mathrm{H} 3 \mathrm{~K} 27 \mathrm{me} 3$ promotes the transcription activation
H3K4me3 mark implicated in Hotairm 1 transcription. Notably, these epigenetic changes were also observed in MDSCs from spleens (Supplementary Figure 1), suggesting that epigenetic modifications at the Hotairm1 promoter are maintained systematically after MDSCs exit the bone marrow. Because Hotairm1 couples with S100A9 to program MDSCs during later sepsis, our findings underscore the importance of removing $\mathrm{H} 3 \mathrm{~K} 4 \mathrm{me} 3$ in limiting excessive MDSC accumulation during later sepsis in humans.

GSK-J4 treatment for $12 \mathrm{~h}$ increased H3K27me3 levels without affecting cell viability. GSK-J4 targeting KDM6A is an effective therapeutic strategy against craniosynostosis (35), lymphoblastic and myeloid leukemias (37, 38), and breast, ovarian and prostate cancers (39-41). Kruidenier et al. (29) reported GSK-J4 as a specific inhibitor of KDM6A's demethylase activity during macrophage inflammatory responses. Mechanistically, GSK-J4 prevents LPS-induced removal of $\mathrm{H} 3 \mathrm{~K} 27 \mathrm{me} 3$ that is present at the TNF $\alpha$ transcription start site and inhibits TNF $\alpha$ expression in human primary macrophages (29). Our results showed that GSK-J4 treatment had no effects on KDM6A protein levels in MDSCs as reported by Kruidenier (29). 


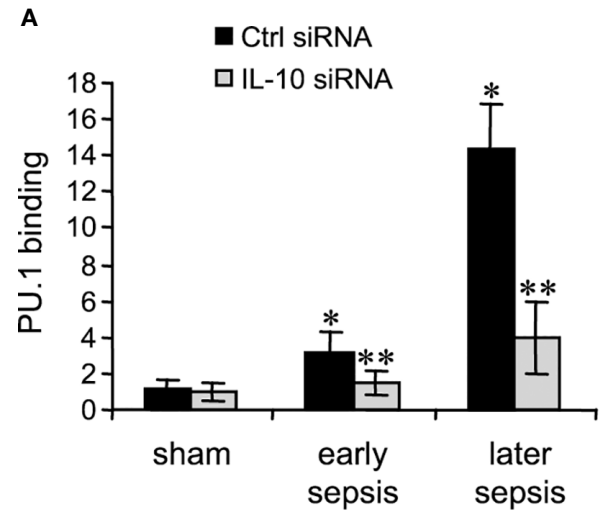

C

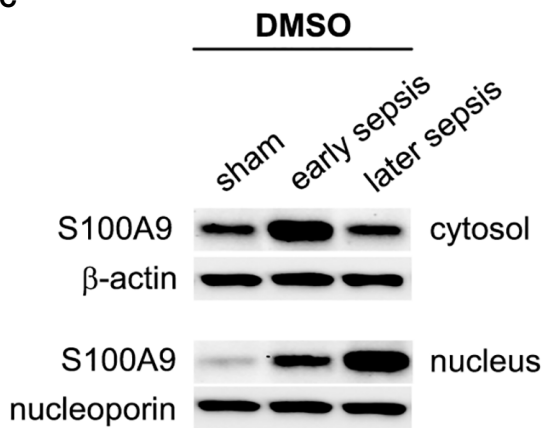

B

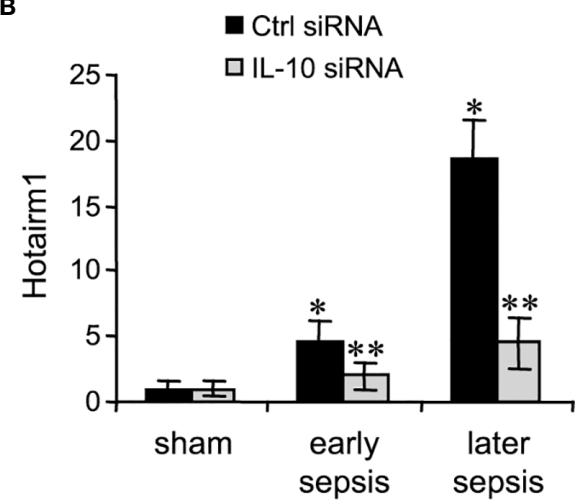

GSK-J4

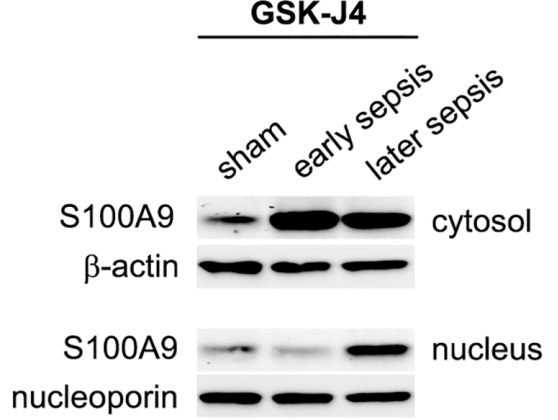

FIGURE 5 | PU.1 binding and Hotairm1 transcripts in MDSCs after IL-10 Knockdown. Gr1+CD11 ${ }^{+}$cells were purified from bone marrow cells and transfected with IL-10-specific or scrambled/control siRNA for 36 h. (A) PU.1 binding at Hotairm1 promoter. Chromatin was immunoprecipitated with antiPU.1 or anti-IgG isotype control antibody. The ChIPed DNA was analyzed by qPCR. Samples values were normalized to the "input" DNA and are presented relative to the IgG-immunoprecipitated samples (1-fold). (B) Total RNA was isolated and Hotairm1 levels were determined by real-time RT-qPCR using qPCR Primer Assay specific to Hotairm1. Sample values were normalized to GAPDH RNA as an internal control and are presented relative to sham (1-fold). Data represent mean \pm SD for 4-6 mice per group, pooled from independent experiments. ${ }^{\star} p<0.05$, early or later sepsis vs. sham; ${ }^{\star \star} p<0.05$, IL-10 siRNA vs. Ctrl siRNA. (C) Inhibition of KDM6A moves S100A9 protein from the nucleus to the cytosol. Western blot analysis of S100A9 protein localization. The cells were incubated with $4 \mu \mathrm{M}$ of GSK-J4 or $0.1 \%$ DMSO for $12 \mathrm{~h}$. Protein extracts were used to determine S100A9 levels in the cytosol and nucleus. The results are representative of two Western blots.

The trimethylation of $\mathrm{H} 3 \mathrm{~K} 27$ by zeste homolog 2 (Ezh2) is part of the epigenetic activity of the mammalian polycomb repressor complex PRC2 (42) and negatively regulates MDSCs in tumor-bearing mice (43). We reported that Ezh2 binds at Hotairm1 promoter in MDSCs with no change in binding levels before and during sepsis (24), but Ezh2 knockdown reduces $\mathrm{H} 3 \mathrm{~K} 27 \mathrm{me} 3$ levels on Hotairm 1 promoter (24). Although both Ezh2 and KDM6A protein expression in MDSCs remains unchanged during sepsis, KDM6A binding at Hotairm 1 promoter increases significantly after sepsis induction. Of note, our results showed that GSK-J4 treatment does not affect either Ezh2 or KDM6A protein levels. We conclude that KDM6A plays an important role in reducing repressor mediator $\mathrm{H} 3 \mathrm{~K} 27 \mathrm{me} 3$ on the Hotairm 1 promoter, thereby increasing Hotairm 1 during sepsis.

Removing H3K27me3 from the Hotairm1 promoter in MDSCs informed transcription activation by increasing the level of H3K4me3 deposition. H3K4Me3 commonly activates gene promoters $(44,45)$, including some lncRNAs $(46,47)$.

Immunosuppressive IL-10 cytokine commonly supports sepsis-induced immunosuppression (48) and its levels increase in mouse MDSCs as sepsis progresses to the later, protracted stage (13). IL-10 supports S100A9 protein translocation to the nucleus in MDSCs (36), concomitant with Hotairm1 binding to S100A9 (18). In this study, we used GSK-J4 treatment to relocate S100A9 to the cytosol in later sepsis MDSCs. By targeting KDM6A demethylase activity, S100A9 nuclear accumulation decreased in MDSCs, supporting the report that mice deficient in S100A9 do not generate MDSCs during sepsis (17). IL-10 knockdown in this study inhibited KDM6A binding at Hotairm 1 promoter, increased $\mathrm{H} 3 \mathrm{~K} 27 \mathrm{me} 3$, decreased $\mathrm{H} 3 \mathrm{~K} 4 \mathrm{me} 3$, and reduced Hotairm 1 levels in a pattern similar to GSKJ4 treatment. 


\section{Sepsis patients}

A

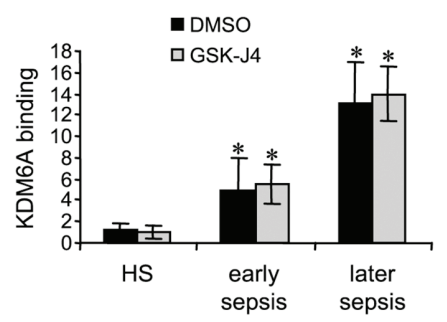

D

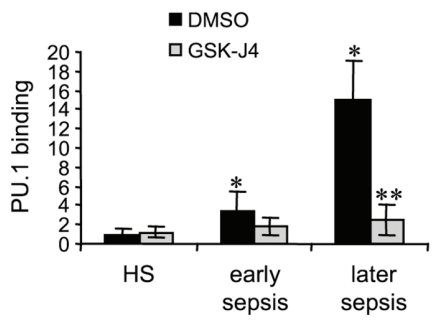

B

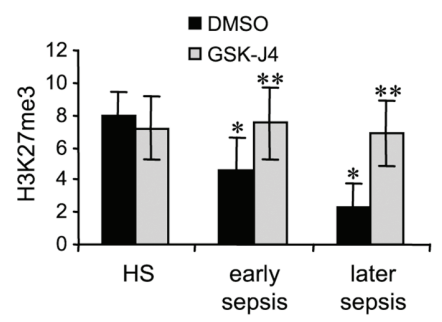

E

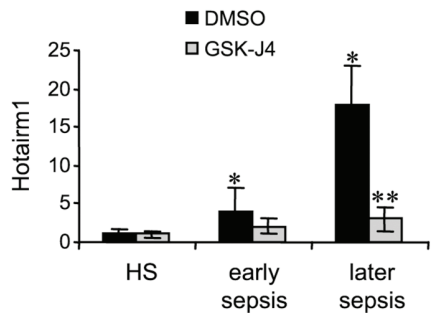

C

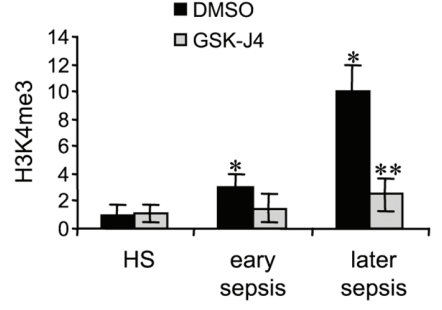

F

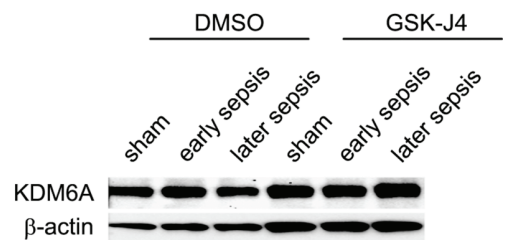

FIGURE 6 | Inhibition of KDM6A attenuates PU.1 binding and Hotairm1 transcription in MDSCs from septic patients. PBMCs were first purified and depleted of the HLA-DR ${ }^{+}$cells using biotin-coupled anti-HLA-DR antibody and anti-biotin microbeads, followed by the positive selection of CD33 $3^{+}$LOX $1^{+}$cells with biotin-coupled anti-CD33 and anti-LOX1 antibodies. These CD33 ${ }^{+}$LOX1 $1^{+} H L A-D R^{-}$cells were incubated with $4 \mu \mathrm{M}$ of GSK-J4 or $0.1 \%$ DMSO for $12 \mathrm{~h}$. (A-D) Chromatin was isolated and immunoprecipitated with anti-KDM6A, anti-H3K27me3, anti-H3K4me3, anti-PU.1, or anti-lgG control antibody. The ChIPed DNA was analyzed by realtime qPCR. Samples values were normalized to the "input" DNA and are presented relative to the lgG-immunoprecipitated samples (1-fold). (E) Total RNA was isolated and Hotairm1 levels were determined by real-time RT-qPCR. Sample values were normalized to GAPDH RNA as an internal control and are presented relative to HS (1-fold). Data represent mean \pm SD for 3-4 patients or HS per group. ${ }^{*} p<0.05$, early or later sepsis vs. HS; ${ }^{* *} p<0.05$, GSK-J4 vs. DMSO.

(F) Western blotting of KDM6A. The results are representative of two Western blots. HS, healthy subjects.

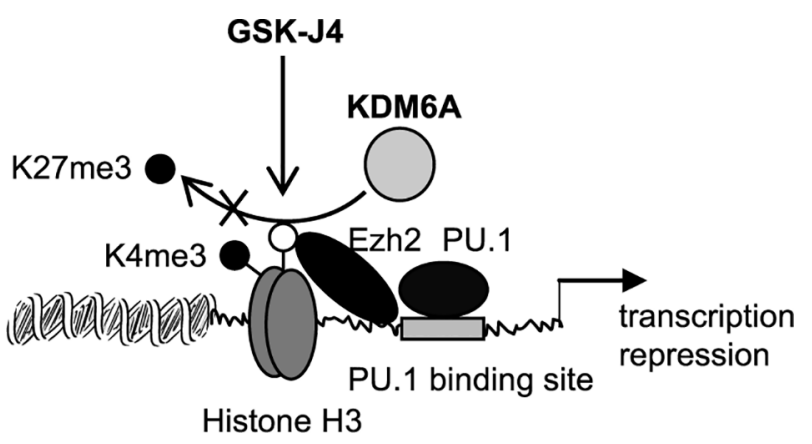

FIGURE 7 | A diagram depicting the effect of GSK-J4 on Hotairm1 transcription in MDSCs. During sepsis, histone demethylase KDM6A binds at the Hotairm1 promoter around the PU.1 binding site and removes K27me3, which is deposited by histone methyltransferase Ezh2. The removal of K27me3 leads to the deposit of $\mathrm{K} 4 \mathrm{me} 3$ and activation of Hotairm1 transcription. This process can be blocked with GSK-J4, which inhibits KDM6A demethylase activity and thus prevents the removal of K27me3, leading to transcription repression of Hotairm1.

In summary, KDM6A demethylase activity is a potential therapeutic target in sepsis MDSCs, acting in part by driving Hotairm 1 transcription. Hotairm1, in turn, modifies the vital inflammatory protein mediator, S100A9. Thus, epigenetic, post-translational, and nuclear protein mediators likely combine to inform MDSC development during later and possibly chronic sepsis with immunosuppression and rising mortality rates. Our findings support that Hotairm 1 targeting is a likely treatment path for protracted sepsis.

\section{DATA AVAILABILITY STATEMENT}

The original contributions presented in the study are included in the article/Supplementary Material. Further inquiries can be directed to the corresponding author.

\section{ETHICS STATEMENT}

The human study was approved by the Institutional Review Board (IRB) of the East Tennessee State University (IRB\#: 0714.6s). All patients provided their written informed consent to participate in this study. All animal experiments were conducted in accordance with National Institutes of Health guidelines and were approved by the 
East Tennessee State University Animal Care and Use Committee (Protocol\#: 190603).

\section{AUTHOR CONTRIBUTIONS}

IB conducted the experiments. DY recruited patients and collected blood samples. ZY provided critical input for experimental design and discussed the results. CM provided insights regarding data interpretation and edited the manuscript. MG designed the study, interpreted the data, and wrote the manuscript. All authors contributed to the article and approved the submitted version.

\section{REFERENCES}

1. Singer M, Deutschman CS, Seymour CW, Shankar-Hari M, Annane D, Bauer $\mathrm{M}$, et al. The Third International Consensus Definitions for Sepsis and Septic Shock (Sepsis-3). JAMA (2016) 315:801-10. doi: 10.1001/jama.2016.0287

2. van der Poll T, Shankar-Hari M, Wiersinga WJ. The Immunology of Sepsis. Immunity (2021) 54:2450-64. doi: 10.1016/j.immuni.2021.10.012

3. Hotchkiss RS, Monneret G, Payen D. Sepsis-Induced Immunosuppression: From Cellular Dysfunctions to Immunotherapy. Nat Rev Immunol (2013) 13:862-74. doi: 10.1038/nri3552

4. Horiguchi H, Loftus TJ, Hawkins RB, Raymond SL, Stortz JA, Hollen MK, et al. Innate Immunity in the Persistent Inflammation, Immunosuppression, and Catabolism Syndrome and its Implications for Therapy. Front Immunol (2018) 9:595. doi: 10.3389/fimmu.2018.00595

5. Torres LK, Pickkers P, van der Poll T. Sepsis-Induced Immunosuppression. Annu Rev Physiol (2022) 84. doi: 10.1146/annurev-physiol-061121-040214

6. Patil NK, Bohannon JK, Sherwood ER. Immunotherapy: A Promising Approach to Reverse Sepsis-Induced Immunosuppression. Pharmacol Res (2016) 111:688-702. doi: 10.1016/j.phrs.2016.07.019

7. Walton AH, Muenzer JT, Rasche DS, Boomer JS, Sato B, Brownstein BH, et al. Reactivation of Multiple Viruses in Patients With Sepsis. PloS One (2014) 9: e98819. doi: 10.1371/journal.pone.0098819

8. Denstaedt SJ, Singer BH, Standiford TJ. Sepsis and Nosocomial Infection: Patient Characteristics, Mechanisms, and Modulation. Front Immunol (2018) 9:2446. doi: 10.3389/fimmu.2018.02446

9. Hawkins RB, Raymond SL, Stortz JA, Horiguchi H, Brakenridge SC, Gardner $\mathrm{A}$, et al. Chronic Critical Illness and the Persistent Inflammation, Immunosuppression, and Catabolism Syndrome. Front Immunol (2018) 9:1511. doi: 10.3389/fimmu.2018.01511

10. Schrijver IT, Theroude C, Roger T. Myeloid-Derived Suppressor Cells in Sepsis. Front Immunol (2019) 10:327. doi: 10.3389/fimmu.2019.00327

11. Veglia F, Sanseviero E, Gabrilovich DI. Myeloid-Derived Suppressor Cells in the Era of Increasing Myeloid Cell Diversity. Nat Rev Immunol (2021) 21:48598. doi: 10.1038/s41577-020-00490-y

12. Sanchez-Pino MD, Dean MJ, Ochoa AC. Myeloid-Derived Suppressor Cells (MDSC): When Good Intentions Go Awry. Cell Immunol (2021) 362:104302. doi: 10.1016/j.cellimm.2021.104302

13. Brudecki L, Ferguson DA, McCall CE, El Gazzar M. Myeloid-Derived Suppressor Cells Evolve During Sepsis and can Enhance or Attenuate the Systemic Inflammatory Response. Infect Immun (2012) 80:2026-34. doi: 10.1128/IAI.00239-12

14. Delano MJ, Scumpia PO, Weinstein JS, Coco D, Nagaraj S, Kelly-Scumpia KM, et al. Myd88-Dependent Expansion of an Immature GR-1(+)CD11b(+) Population Induces T Cell Suppression and Th2 Polarization in Sepsis. J Exp Med (2007) 204:1463-74. doi: 10.1084/jem.20062602

15. Efron PA, Mohr AM, Bihorac A, Horiguchi H, Hollen MK, Segal MS, et al. Persistent Inflammation, Immunosuppression, and Catabolism and the Development of Chronic Critical Illness After Surgery. Surgery (2018) 164:178-84. doi: 10.1016/j.surg.2018.04.011

16. Janols H, Bergenfelz C, Allaoui R, Larsson A, Rydén L, Björnsson S, et al. A High Frequency of Mdscs in Sepsis Patients, With the Granulocytic Subtype

\section{FUNDING}

This work was supported by a National Institutes of Health grant R35GM131692 (to MG). CM is supported by an NIGMS grant R35GM126922.

\section{SUPPLEMENTARY MATERIAL}

The Supplementary Material for this article can be found online at: https://www.frontiersin.org/articles/10.3389/fimmu.2022. 823660/full\#supplementary-material

Dominating in Gram-Positive Cases. J Leukoc Biol (2014) 96:685-93. doi: 10.1189/jlb.5HI0214-074R

17. Dai J, Kumbhare A, Youssef D, McCall CE, El Gazzar M. Intracellular S100A9 Promotes Myeloid-Derived Suppressor Cells During Late Sepsis. Front Immunol (2017) 8:1565. doi: 10.3389/fimmu.2017.01565

18. Alkhateeb T, Bah I, Kumbhare A, Youssef D, Yao ZQ, McCall CE, et al. Long Non-Coding RNA Hotairm1 Promotes S100A9 Support of MDSC Expansion During Sepsis. J Clin Cell Immunol (2020) 11:600.

19. Abhimanyu, Ontiveros CO, Guerra-Resendez RS, Nishiguchi T, Ladki M, Hilton IB, et al. Reversing Post-Infectious Epigenetic-Mediated Immune Suppression. Front Immunol (2021) 12:688132. doi: 10.3389/fimmu.2021.688132

20. Cross D, Drury R, Hill J, Pollard AJ. Epigenetics in Sepsis: Understanding its Role in Endothelial Dysfunction, Immunosuppression, and Potential Therapeutics. Front Immunol (2019) 10:1363. doi: 10.3389/fimmu.2019.01363

21. El Gazzar M, Yoza BK, Chen X, Garcia BA, Young NL, McCall CE. Chromatin-Specific Remodeling by HMGB1 and Linker Histone H1 Silences Proinflammatory Genes During Endotoxin Tolerance. Mol Cell Biol (2009) 29:1959-71. doi: 10.1128/MCB.01862-08

22. Vachharajani V, McCall CE. Epigenetic and Metabolic Programming of Innate Immunity in Sepsis. Innate Immun (2019) 25:267-79. doi: 10.1177/ 1753425919842320

23. Otto GP, Sossdorf M, Claus RA, et al. The Late Phase of Sepsis is Characterized by an Increased Microbiological Burden and Death Rate. Crit Care (2011) 15:R183. doi: 10.1186/cc10332

24. Bah I, Alkhateeb T, Youssef D, Yao ZQ, McCall CE, El Gazzar M. KDM6A Lysine Demethylase Directs Epigenetic Polarity of MDSCs During Murine Sepsis. J Innate Immun (2021) 13:1-12. doi: 10.1159/000517407

25. Agger K, Cloos PA, Christensen J, Pasini D, Rose S, Rappsilber J, et al. UTX and JMJD3 are Histone H3K27 Demethylases Involved in HOX Gene Regulation and Development. Nature (2007) 449:731-4. doi: 10.1038/ nature 06145

26. Hong S, Cho YW, Yu LR, Yu H, Veenstra TD, Ge K. Identification of Jmjc Domain-Containing UTX and JMJD3 as Histone H3 Lysine 27 Demethylases. Proc Natl Acad Sci USA (2007) 104:18439-44. doi: 10.1073/pnas.0707292104

27. Kouzarides T. Chromatin Modifications and Their Function. Cell (2007) 128:693-705. doi: 10.1016/j.cell.2007.02.005

28. Lee MG, Villa R, Trojer P, Norman J, Yan K, Reinberg D, et al. Demethylation of H3K27 Regulates Polycomb Recruitment and H2A Ubiquitination. Science (2007) 318:447-50. doi: 10.1126/science.1149042

29. Kruidenier L, Chung CW, Cheng Z, Liddle J, Che K, Joberty G, et al. A Selective Jumonji H3K27 Demethylase Inhibitor Modulates the Proinflammatory Macrophage Response. Nature (2012) 488:404-8. doi: 10.1038 /nature 11262

30. Angele MK, Schwacha MG, Ayala A, Chaudry IH. Effect of Gender and Sex Hormones on Immune Responses Following Shock. Shock (2000) 14:81-90. doi: 10.1097/00024382-200014020-00001

31. De MA, Torres MB, Reeves RH. Genetic Determinants Influencing the Response to Injury, Inflammation, and Sepsis. Shock (2005) 23:11-7. doi: 10.1097/01.shk.0000144134.03598.c5

32. Zellweger R, Wichmann MW, Ayala A, Stein S, DeMaso CM, Chaudry IH. Females in Proestrus State Maintain Splenic Immune Functions and Tolerate 
Sepsis Better Than Males. Crit Care Med (1997) 25:106-10. doi: 10.1097/ 00003246-199701000-00021

33. Brudecki L, Ferguson DA, Yin D, Lesage GD, McCall CE, El Gazzar M. Hematopoietic Stem-Progenitor Cells Restore Immunoreactivity and Improve Survival in Late Sepsis. Infect Immun (2012) 80:602-11. doi: 10.1128/ IAI.05480-11

34. Mazuski JE, Sawyer RG, Nathens AB, DiPiro JT, Schein M, Kudsk KA, et al. The Surgical Infection Society Guidelines on Antimicrobial Therapy for IntraAbdominal Infections: An Executive Summary. Surg Infect (Larchmt) (2002) 3:161-73. doi: 10.1089/109629602761624171

35. Pribadi C, Camp E, Cakouros D, Anderson P, Glackin C, Gronthos S. Pharmacological Targeting of KDM6A and KDM6B, as a Novel Therapeutic Strategy for Treating Craniosynostosis in Saethre-Chotzen Syndrome. Stem Cell Res Ther (2020) 11:529. doi: 10.1186/s13287-020-02051-5

36. Bah I, Kumbhare A, Nguyen L, McCall CE, El Gazzar M. IL-10 Induces an Immune Repressor Pathway in Sepsis by Promoting S100A9 Nuclear Localization and MDSC Development. Cell Immunol (2018) 332:32-8. doi: 10.1016/j.cellimm.2018.07.003

37. Benyoucef A, Palii CG, Wang C, Porter CJ, Chu A, Dai F, et al. UTX Inhibition as Selective Epigenetic Therapy Against TAL1-Driven T-Cell Acute Lymphoblastic Leukemia. Genes Dev (2016) 30:508-21. doi: 10.1101/ gad.276790.115

38. Yapp C, Carr AJ, Price A, Oppermann U, Snelling SJ. H3k27me3 Demethylases Regulate In Vitro Chondrogenesis and Chondrocyte Activity in Osteoarthritis. Arthritis Res Ther (2016) 18:158. doi: 10.1186/s13075-016-1053-7

39. Morozov VM, Li Y, Clowers MM, Ishov AM. Inhibitor of H3K27 Demethylase JMJD3/UTX GSK-J4 Is a Potential Therapeutic Option for Castration Resistant Prostate Cancer. Oncotarget (2017) 8:62131-42. doi: 10.18632/oncotarget. 19100

40. Sakaki H, Okada M, Kuramoto K, Takeda H, Watarai H, Suzuki S, et al. Gskj4, a Selective Jumonji H3k27 Demethylase Inhibitor, Effectively Targets Ovarian Cancer Stem Cells. Anticancer Res (2015) 35:6607-14.

41. Yan N, Xu L, Wu X, Zhang L, Fei X, Cao Y, et al. GSKJ4, an H3k27me3 Demethylase Inhibitor, Effectively Suppresses the Breast Cancer Stem Cells. Exp Cell Res (2017) 359:405-14. doi: 10.1016/j.yexcr.2017.08.024

42. Chittock EC, Latwiel S, Miller TC, Muller CW. Molecular Architecture of Polycomb Repressive Complexes. Biochem Soc Trans (2017) 45:193-205. doi: 10.1042/BST20160173
43. Huang S, Wang Z, Zhou J, Huang J, Zhou L, Luo J, et al. EZH2 Inhibitor GSK126 Suppresses Antitumor Immunity by Driving Production of MyeloidDerived Suppressor Cells. Cancer Res (2019) 79:2009-20. doi: 10.1158/00085472.CAN-18-2395

44. Bernstein BE, Humphrey EL, Erlich RL, Schneider R, Bouman P, Liu JS, et al. Methylation of Histone H3 Lys 4 in Coding Regions of Active Genes. Proc Natl Acad Sci USA (2002) 99:8695-700. doi: 10.1073/pnas.082249499

45. Santos-Rosa H, Schneider R, Bannister AJ, Sherriff J, Bernstein BE, Emre NC, et al. Active Genes are Tri-Methylated at K4 of Histone H3. Nature (2002) 419:407-11. doi: 10.1038/nature01080

46. Derrien T, Johnson R, Bussotti G, Tanzer A, Djebali S, Tilgner H, et al. The GENCODE V7 Catalog of Human Long Noncoding Rnas: Analysis of Their Gene Structure, Evolution, and Expression. Genome Res (2012) 22:1775-89. doi: $10.1101 /$ gr.132159.111

47. Guttman M, Amit I, Garber M, French C, Lin MF, David Feldser D, et al. Chromatin Signature Reveals Over a Thousand Highly Conserved Large nonCoding Rnas in Mammals. Nature (2009) 458:223-7. doi: 10.1038/ nature 07672

48. Bergmann CB, Beckmann N, Salyer CE, Hanschen M, Crisologo PA, Caldwell CC. Potential Targets to Mitigate Trauma- or Sepsis-Induced Immune Suppression. Front Immunol (2021) 12:622601. doi: 10.3389/fimmu.2021.622601

Conflict of Interest: The authors declare that the research was conducted in the absence of any commercial or financial relationships that could be construed as a potential conflict of interest.

Publisher's Note: All claims expressed in this article are solely those of the authors and do not necessarily represent those of their affiliated organizations, or those of the publisher, the editors and the reviewers. Any product that may be evaluated in this article, or claim that may be made by its manufacturer, is not guaranteed or endorsed by the publisher.

Copyright $\odot 2022$ Bah, Youssef, Yao, McCall and El Gazzar. This is an open-access article distributed under the terms of the Creative Commons Attribution License (CC BY). The use, distribution or reproduction in other forums is permitted, provided the original author(s) and the copyright owner(s) are credited and that the original publication in this journal is cited, in accordance with accepted academic practice. No use, distribution or reproduction is permitted which does not comply with these terms. 